\title{
Service Dominant Logic, Open Innovation Intermediaries and Innovative Capacities: Towards a Theoretical Framework
}

\author{
Mirko Perano ${ }^{1}$, Gian Luca Casali ${ }^{2} \&$ Tindara Abbate $^{3}$ \\ ${ }^{1}$ Department of Management, Reald University College, Vlore, Albania \\ ${ }^{2}$ Business School Management, Queensland University of Technology, Brisbane, Australia \\ ${ }^{3}$ Department of Economics, University of Messina Italy \\ Correspondence: Mirko Perano, Department of Management, Reald University College, Vlore, Albania. E-mail: \\ mperano@unisa.it
}

Received: July 12, 2018

doi:10.5539/ijbm.v13n10p146
Accepted: August 17, 2018

Online Published: September 7, 2018

\begin{abstract}
This work stresses the centrality of the Service-Dominant Logic (S-D logic) point of view and the relationships between firm and Open Innovation Intermediary in the knowledge development process providing a conceptual framework. From an indepth literature review on S-D logic, Open Innovation Intermediaries and firm dynamic capabilities, a development of a conceptual framweork based on these research areas is provided. The framework is intended to highlight the role of customers (firms) into professional relationships with intermediaries of innovation becomes progressively significant in the innovation activities because these professional relationships increasingly become co-creators of value. Within their advanced platforms, intermediaries or brokers, encourage, promote and sustain interactions and partnerships aligned to value co-creation enterprises. This is achieved by providing a heterogeneous set of services to augment dynamic cooperation, to advance concepts or solutions for solving interdisciplinary problems and, consequently, to address an organisation's requirements for new market opportunities. Therefore, these partnerships represent a possible way to define and to improve the value cocreation actions by firms that intend to engage and to cooperate with adjunctive and integrative resources and expertise. In addition, the framework has been designed to highlight a particular domain centred on the the role of each S-D Logic axioms within the innovation capabilities; and the relationship and orientation between organisation and innovation intermediary. The main findings highlight that both firms and Open Innovation Intermediaries need to develop innovative capabilities through direct and indirect relationships within the S-D logic perspective. This study is an effort towards building a conceptual framework by connecting the concepts of Open Innovation Intermediaries, dynamic capabilities and S-D logic.
\end{abstract}

Keywords: Service-Dominant Logic; Open Innovation Intermediaries; web-based platforms; value cocreation; innovative capacities; direct and indirect relationships

\section{Introduction}

The service concept is progressively interested by a relevant conceptual revolution in the 21 st century. According with Alter (2008) "there is surprisingly little agreement about definition of service and service innovation" (p. 63). Rai \$ Sambamurthy (2006) coined a "triangulation" which referred to the definition of the term "service" (p. 328). They point out that there is reasonable triangulation on what services are...in general, the definitions emphasize a simultaneous or near-simultaneous exchange of production and consumption, transformation in the experience and value that customers receive from engagement with providers, and intangibility in that goods are not exchanged" (Rai \& Sambamurthy, 2006, p. 328). 
Table 1. An overview of service definition

\section{DEFINITION OF "SERVICE"}

Services are "activities, benefits or satisfactions which are offered for sale, or are provided in connection with the sale of good".

"A service is a change in the condition of a person, or a good belonging to some economic entity, brought about as a result of some other economic entity, with the approval of the first person or economic entity".

Services are "the application of specialized competencies (knowledge and skills) through deeds, processes, and performances for the benefit of another entity of the entity itself".

"with service processes, the customer provides significant inputs into the production process".

"A service is a time-perishable, intangible experience performed for a customer acting in the role of a coproducer".

"A service is any act or performance that one party can offer to another that is essentially intangible and does not result in the ownership of anything".

Service is "the application of competences (knowledge skills, and resources) for the benefit of another entity in a mutually agreed and mutually beneficial manner".

"Service [is] the application of resources for the benefit of another".

Source: adapted from Alter, 2008, p. 63

\section{SOURCE}

American Marketing Association 1960, p. 21

Hill 1977, p. 318

Vargo and Lusch 2004, p. 2

Sampson and Froehle 2006, p. 331

Fitzsimmons and Fitzsimmons 2006, p. 4

Kotler and Keller 2006, p. 402

IfM and IBM 2007, p. 16

Vargo and Lusch cited in Spohrer et al. 2008, p. 1

Reviewing the work of Vargo \& Lusch (2004) the service has become central to the goods, identifying a new dominant logic. Specifically, "service" and not "services" because the first "implies a process" while the second "implies units of output and therefore reflects the goods-dominant logic" that for Vargo \& Lusch indicate "is flawed" (Lusch \& Vargo, 2006, p. xvii). Therefore, the "goods have become mere instruments in service delivery so that service are now exchanged for service" (Lusch \& Vargo, 2006, p. 118). This radical change in the marketing field has also had an impact on service science here intended as "a transdisciplinary approach to study, improve, create, scale, and innovate in service" (Demirkan et al, 2011, p. 1 and Spohrer \& Maglio, 2008, 2009). All these activities are included in the processes, connected with processes of each other in an ecosystem. By this way, service systems are "such entities, be they individuals, firms, or nations" (Krishna, 2011, p. 1).

Spohrer et al. (2007) define service system as a "collection of resources that can create value with other service system through shared information" (p. 1). This implies that in the service system the connections (the link) and the interactions make up the condition for sharing information and knowledge, and so for the value co-creation. The interactions must be understood as a suitable exchange characterized by a reciprocal benefit (i.e., economic, knowledge, competence, experience, resource, skill, etc.) or better with "mutual or reciprocal action or influence" (Merriam Webster, 2015). All this overcomes the simple concept of transaction and underlines the relevance of the value co-creation concept. Considering the overcoming of transactional enterprise, in the last decade a particular scientific attention has been placed on the service that has become the fulcrum of theoretical framework and paradigms proposed in the literature.. Among these paradigms, there is the S-D logic proposed in the marketing area and Open Innovation Intermediaries (OIIs) advanced in the management literature. Specifically, S-D Logic can be observed as "a mind-set, a lens through which to examine social and economic exchange phenomena" (Vargo \& Lusch, 2008, p. 9), by underlining that the concept of resource integration is more useful as it reflects what actually occurs when actors (e.g. customers, buyers, suppliers) are oriented to interact and to collaborate. OIIs are contemplates as third organizations that provide a relevant role for the collaborations among different entities during the articulate stage of the innovation activities/processes (Howells, 2006). More specifically, they stimulate and sustain the interactions and relationships between seekers (firms looking for innovative solutionsto their problems) and solvers (i.e., experts, researchers, professionals, users, firms, etc.) by playing different functions and providing a wider range of services, thus potentially providing suitable and applicable solutions (Howells 2006; Sieg et al. 2010; Aquilani et al. 2017). With this in mind, the aim of this paper is twofold. Firstly, it is oriented to point out the relevance of the role of customers (firms) into relationships and collaborations with intermediaries in the innovation paths. This is because they are becoming more as co-creators of value, moving from their contribution in the new product development. Within their technological platforms with different components and tools, intermediaries of innovation promote, facilitate and sustain ongoing interactions and collaborations directed to value cocreation activities. Thus, by providing a heterogeneous set of services to enhance involvement and participation, to develop ideas/products/solutions to 
different problems related to interdisciplinary arenas and, consequently, to try to produce an appropriate answer to firm's needs or to identify suitable market opportunities. Therefore, they represent a possible and positive way to define and to support processes of co-creation by organizations that are more oriented to involve and to cooperate with adequate complementary resources and competencies. Additionally, it is aimed to illuminate that the unique domain, which the axioms of S-D Logic assume within innovation capabilities literature and the relationship between firm and innovation intermediary, are more oriented to.

Starting fom the main contributions in literature dedicated to S-D logic, OIIs and firm dynamic capabilities to define a conceptual framework, the paper underlines that both firms and OIIs need to develop innovative capabilities through direct and indirect relationships within the context of S-D logic.

This study also represents an effort towards building a conceptual framework by connecting the concepts of OIIs, dynamic capabilities and S-D logic and providing an integrative perspective. Specifically, this integrates the current literature of S-D logic into that of OI in order to conceptualize the contribution of OIIs in shaping the collaborations and relationships between firms and external knowledge sources. This research extends the concept of innovative capabilities that dominates the existing OI literature. In the first theoretical part of the paper the S-D logic, the Open Innovation Intermediary are addressed. In regard to the S-D logic, foundational premises and axioms through an overview of the literature are discussed. Relatively to the OII, their principal role, functions and services provided within their advanced platforms and firm innovative capabilities which are required to obtain new knowledge and complementary competences by different external entities are argued. In the final part of the paper the conteptual framework with the conclusions, limitations and future research are summarized.

\section{Literature Review}

\subsection{From S-D Logic to Five Axioms of Research}

Several authors and different perspectives have enriched the S-D logic, by adapting to specific competitive arena and relating to multiplicity approaches in order to highlight its usefulness in the understanding of exchange processes. S-D Logic is "[...] an alternative to the current (goods-) dominant logic", "[...] a lens, mind-set, through which phenomena can be viewed" (Vargo, 2007, p. 105). S-D logic is centered on the serving process for heterogeneus parties, i.e. individuals, organizations, entities, firms, network or customers. Each of these skills, competences and capabilities, exchange and interact with the others to activate and potentially develop the value cocreation process and for additional mutual benefits (Vargo \& Lusch, 2004). This extended marketing (but not only) framework sanctions the transition from a logic of goods to a more evolved of services and at the same time the transition from products to value propositions co-obtained with the active participation of the actors involved. So, service is a merging concept for the necessary understanding of economic and social exchanges characterizing all economies (Lusch \& Vargo, 2014) and cannot be observed as an alternative form of product because it represents "the general and universal case, the common denominator, of the exchange process; service is what is always exchanged. Goods, when employed are aids to the service process" (Lusch \& Nambisan, 2015, pp. 158-159). Under this lens, the above-mentioned logic underlines "service-for-service exchange between actors and within network of actors in service systems" (Lusch \& Vargo, 2014, p. 113), actor-to-actor orientation (A2A) moving out of the traditional role of producers/customers and/or firms/customers (Vargo \& Lusch, 2016). Additionally, it highlights the value-centric viewpoint from value-in use (Vargo \& Lusch, 2004), value-in context (Chandler \& Vargo, 2011) and value-in-social-context (Edvardsson, Tronvol \& Gruber, 2011). S-D Logic is firstly based on eleven fundamental premises (FPs) that represent a valuable mind-set to revisit what is concretely exchanged, what is offered and how interaction among diverse entities should operate in an efficacious way (Vargo \& Lusch, 2004; Vargo et al., 2008). Then, these premises have been redefined in order to propose a framework or lens for observing effectively diverse actors in their process of exchange. These actors are observed "becoming more specialized and thus needing to more intensively and extensively exchange service, integrate resources, and create and use resources to enhance the viability of the relevant system(s) within which they are embedded" (Lusch \& Vargo, 2014, p.80). Among these foundational premises, it is possible to consider the five axioms of S-D logic (Vargo \& Lusch, 2016) (see tab. 2). 
Table 2. S-D Logic fundamental premise and axioms

\begin{tabular}{|c|c|c|c|}
\hline FPs & FOUNDATIONAL PREMISES & COMMENT/EXPLANATION & AXIOMS \\
\hline 1 & $\begin{array}{l}\text { Service is the fundamental basis of } \\
\text { exchange }\end{array}$ & $\begin{array}{l}\text { The application of operant resources (knowledge } \\
\text { and skills), "service," as defined in S-D logic, is the } \\
\text { basis for all exchange. Service is exchanged for } \\
\text { service. }\end{array}$ & 1 \\
\hline 2 & $\begin{array}{l}\text { Indirect exchange masks the fundamental } \\
\text { basis of exchange }\end{array}$ & $\begin{array}{l}\text { Because service is offered through diverse } \\
\text { combinations of goods, money, and institutions, the } \\
\text { service basis of exchange is not always apparent. }\end{array}$ & \\
\hline 3 & $\begin{array}{l}\text { Goods are distribution mechanism for } \\
\text { service provision }\end{array}$ & $\begin{array}{l}\text { Goods (both durable and non-durable) originate their } \\
\text { value through use - the service they effectively offered. }\end{array}$ & \\
\hline 4 & $\begin{array}{l}\text { Operant resources are the fundamental } \\
\text { source of strategic benefit. }\end{array}$ & $\begin{array}{l}\text { The possibility of a beneficiary's alternative source of } \\
\text { service is more relevant to service provision. }\end{array}$ & \\
\hline 5 & All economics are service economies & $\begin{array}{l}\text { Service (singular) is only now becoming more } \\
\text { superficial with the improved specialization and } \\
\text { outsourcing. }\end{array}$ & \\
\hline 6 & $\begin{array}{l}\text { Value is co-created by multiple actors, } \\
\text { always including the beneficiary. }\end{array}$ & Implies multi-actor orientation to value creation. & 2 \\
\hline 7 & $\begin{array}{l}\text { Actors cannot deliver value but can } \\
\text { participate in the creation and offering of } \\
\text { value propositions. }\end{array}$ & $\begin{array}{l}\text { Actors can provide their applied resources for value } \\
\text { creation activities and collaboratively (interactively) } \\
\text { can create value following acceptance of propositions } \\
\text { but cannot create and/or deliver value in an independent } \\
\text { manner. }\end{array}$ & \\
\hline 8 & $\begin{array}{l}\text { A service-centered view is inherently } \\
\text { beneficiary oriented and relational. }\end{array}$ & $\begin{array}{l}\text { The focus is on the beneficiary as the recipient of } \\
\text { service and the referent of value co-creation. This latter } \\
\text { implies the reciprocity of exchange. }\end{array}$ & \\
\hline 9 & $\begin{array}{l}\text { All social and economic actors are } \\
\text { resource integrators }\end{array}$ & $\begin{array}{l}\text { Implies the context of value creation is networks of } \\
\text { networks (resource integrators). }\end{array}$ & 3 \\
\hline 10 & $\begin{array}{l}\text { Value is always uniquely and } \\
\text { phenomenological determined by the } \\
\text { beneficiary }\end{array}$ & $\begin{array}{l}\text { Value is contextual, idiosyncratic, experiential, and } \\
\text { meaning-laden. }\end{array}$ & 4 \\
\hline 11 & $\begin{array}{l}\text { Value co-creation is coordinated through } \\
\text { actor-generated institutions and } \\
\text { institutional arrangements. }\end{array}$ & $\begin{array}{l}\text { Actor-generated institutions are concretely rules and } \\
\text { institutional arrangements are observed as sets of } \\
\text { institutions that together represent a coherent } \\
\text { assemblage oriented to simplify the coordination of } \\
\text { activities in value co-creation service ecosystems. }\end{array}$ & 5 \\
\hline
\end{tabular}

Source: our elaboration on Vargo \& Lusch, 2016.

The first axiom is also the first FP: "Service is the fundamental basis of exchange".

In the context of innovation, the services, assumed as pure third sector, included information, knowledge, skill and competencies from an actor (called transmitting), that intends to offers this proposal of business, to another actor (defined receiving) that is oriented to use them for personal needs or inside his business processes (Perano et al., 2016). In S-D Logic mind-set, as already explained, in all sector "services are exchanged for services". In a market perspective and in the context ofthe third service sector, what binds a transmitter from a receiver is an orientation and propensity to relationships (from both a cultural point of view and skills) and the endowement of critical resources, in line with the ethical principles of the company.

The second axiom is the sixth FP: "Value is co-created by multiple actors, always including the beneficiary".

The value co-creation process "does not just take place through the activities of a single actors (customer or otherwise) or between a firm and its customers but among a whole host of actors" (Vargo \& Lusch, 2016, p. 9). In this respect, effectively, the "value is cocreted by multiple actors, always including the beneficiary" (Vargo \& Lusch, 2016, p. 9). After contact between firm and the whole host of actors (in which there are a transmitting and a receiving), as results of a relational approach, there is a concrete interaction and, probably, an effective cooperation activity, to satisfy the reciprocal expectations and wellbeing.

The third axiom is the ninth FP: "All social and economic actors are resource integrators".

The resources originate from a variety of sources (i.e., individual, public, private, market, etc.) and their integration and combination "not only occurs with the resources directly available to actors involved in an exchange (...) also indirectly with resources and actors that provide these resources in a network" (Lusch \& Vargo, 2014, p. 16). Each social and economic actor considers and perceives the value, so it "must be assessed separately" (Lusch \& Vargo, 2016, p. 10) in order to maximize the satisfaction of each actor and finally to obtain 
more from value cocreation process.

The fourth axiom is the tenth FP: "Value is always uniquely and phenomenological determined by the beneficiary".

The cocreation value can be viewed as a result of collective efforts by peoples, firm, entities, stakeholder, network, customer, but the value is continuously derived by the beneficiary (Vargo \& Lusch, 2006). As stated in the second axiom, the beneficiary of value is essentially considered as the actor and (directly or indirectly) the resource integrator if is an active part. The first one has promoted the relationship direct to achieve a common objective and have activated an ongoing interaction finalized to the value of cocreation activity; the second one, if involved, are aimed to participate to this value creation process. Then, the actors state: (a) the degree of relationship among different parts; (b) the involvement (and the degree of the collaboration) of resource integrators, finally the beneficiaries (i.e. the customer) determine the creation of value.

The fifth axiom is the eleventh FP: "Value co-creation is coordinated through actor-generated institutions and institutional arrangements". Actor-generated institutions are effectively rules (i.e., norms) and institutional arrangements are sets of institutions that together can be sees as a coherent collection aims to facilitate the coordination activity in value cocreation service ecosystems (Vargo \& Lusch, 2016).

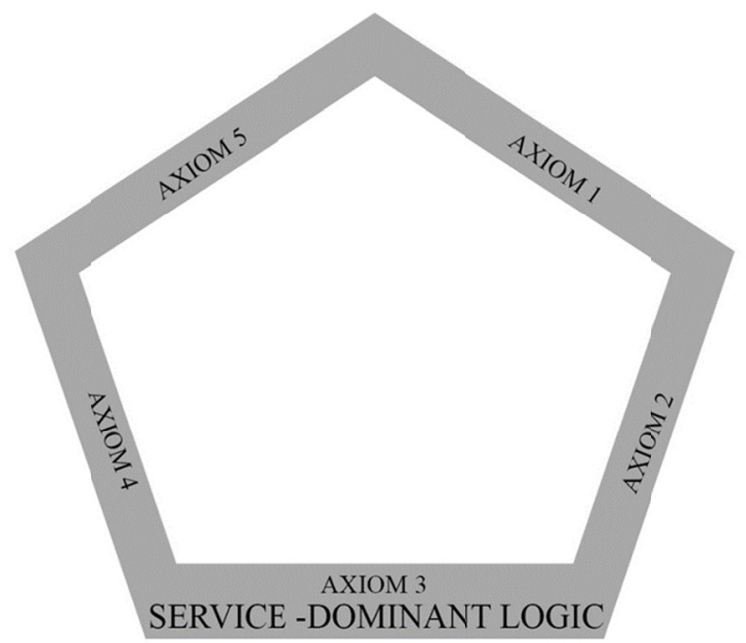

Figure 1. The five axioms in S-D logic. Source: Vargo \& Lusch, 2016

As in evidence (from theoretical and practical perspective), the relational aspects are functional in the third sector of service; very well if suited in a point of view that reads service exchanged for service S-D-logic). In this context, the interactions become the basis of cooperation activity. From this point, it can potentially bring out relationships founded on the value concept and not on the rules (Polese, 2013). From relationships it can built an efficacious network which can be observed as a common acknowledgment of vallues, culture and shared informal rules that, if any, may be formalized through (e.g.) an appropriate agreement or contract form (see Spohrer et al., 2008). In this respect, parties should obtain equilibrium when all parties are operating for the value co-creation; if "[...] one party being the creator of value and the other being a destroyer makes no sense" (Maglio et al, 2009, p. 399). This view, characterized by a relational dimension, shows a good interaction with abstraction of service system by Maglio et al. (2009).

In this study, service system is assumed as an interaction between entities: "[...] service involves at least two entities, one applying competence and another integrating the applied competences with other resources (value cocreation) and determining benefit" (Maglio et al, 2009, p. 399). Also, service system can be described "[...] as a dynamic value co-creation configuration of resources, including people, organizations, shared information (language, laws, measures, methods), and technology, all connected internally and externally to other service systems by value propositions" (Spohrer et al., 2007, p. 73; Spohrer et al. 2008, p. 5).

In the context of OII, i.e., the relational capabilities are one key that, along with others as the criticality of the resource (material or immaterial) owned, can potentially contribute to solve the problem of competitiveness from the side of intermediary and the problem of innovation (i.e.) from the side of the firm. Without relational capabilities, which require a relational vision, firms (intermediaries) and customers (organizations), also other 
figure may, potentially, losing value: resource integrators. As argued above and according with FP8, the aspect of relationship is particularly critical. Having the S-D logic proposed a terminological change that tends, inter alia, to overcome from concept to goods in service and from producer to customer, it is logical to imagine that this perspective tends naturally to maximize the value and impact of the concept of relation. It is from these relationships that firms glean mutual benefits with local or glocal stakeholders (or only resources) in finding investment funds, commercial consensus, or that information necessary or viable to ensure its survival.

Relational aspect is involved in human and organisational aspect (also in the service system), in the social science, that are some of the issues (together mathematical modelling of service systems and its cultural components) of most well know "service science" (Chesbrough \& Spohrer, 2006; Spohrer, et al., 2007). "Service "science" refers to understanding of the origins and life cycles of service systems, ranging from business components, to business models, to value networks of many businesses linked globally" (Spohrer, 2008, pp. 6 and next.). The networks originated from relations, revisited from service systems perspective, can be "macro" and "micro": first "[...] refers to departments or work groups on business components providing service within a business"; second "[...] refers to value networks or value chains composed of many businesses" (Spohrer, 2007, p. 3).

These concerns assume a particular relevance in the context of third sector and Open Innovation (OI) and so for Intermediaries. The concept of Open Innovation (OI) is namely "[...] the use of purposive inflows and outflows of knowledge to accelerate internal innovation and expand the markets for external use of innovation" (Chesbrough, 2003a, 2003b and next).

In a highly innovative context, like that of OII, the relational capabilities (meaning as the abilities to generate an acceptable equilibrium between quantity and quality of relations with the stake), and information and knowledge to be exchanged, are to be considered as fundamental assets to achieve and maintain acceptable levels of competitiveness for survival. From a service point of view, this assumption seems even more valid.

\subsection{Open Innovation Intermediaries: Roles, Functions and Services}

The Open Innovation paradigm provides a solid process of open innovation. This process tends to improve and sustain an adequate and active collaboration among the diverse external actors to conceive, develop, allocate and commercialize the innovation outcomes. All this helps to preserve the competitive advantage and putting on the market products or services in advance compared to other firms (Chesbrough, 2003a; Gassmann, 2006; Chesbrough et al., 2006; Dahlander \& Gann, 2010; Vanhaverbeke \& Du, 2010; Huizingh, 2011). Under this lens, the innovation is no longer a single, sequential process of internal R\&D activities, but an interactive process of exploration and exploitation of innovative input developed between the firm's internal resources and external actors or partners. These external sources can be customers, organizations, suppliers, experts, research centers, universities, private/public R\&D institutions, competitors, and the general community as a whole. In this way, all these actors/partners can have advantages arising from many opportunities (Boudreau \& Lakhani, 2009) that consist in the acquisition of complementary resources and competencies, necessary to explore innovative results useful to:

1) Capture the market necessities (West \& Gallagher, 2006)

2) Spread and share risks, to enlarge networks (also social) and alliances (Enkel, 2010);

3) Diminish costs and increase effectiveness and efficiency (Hoffman \& Scholesser, 2001).

However, the above-mentioned activities, realized with partners (across different contexts and backgrounds) are not straightforward and characterized by multiple problems related to their appropriate definition and, consequently, their concrete implementation (i.e. Van de Vrande et al., 2009; Ollila \& Elmquist, 2011). In this respect, firms can be sustained by the intermediary organizations that assume an important role in the articulated stages of innovation process, moving from the idea generation and development, to commercialization of the products (Sawhney et al., 2005). These intermediary organizations intend to facilitate interactions, participation and relationships among the heterogeneous entities involved in the innovation activities (Howells, 2006; Stewart \& Hyysalo, 2008; Sieg et al., 2010; Abbate \& Coppolino, 2011; Hakanson et al., 2011; Ollila \& Elmquist, 2011; Ye \& Kankahalli, 2013; Aquilani et al., 2017). By this way, they fill up the knowledge gaps existing among different partners and, successively, move towards overcoming the inevitable mismatching.

These organizations, operating in diverse several ways across different domain areas and sectors, are oriented to realize effective intermediation activities (see figure 2) through the stimulation of the innovation processes that leverage with the involvement of a useful network of external resources and competencies. Additionally, supporting their customers (considered as innovation seekers) to effectively catch the new opportunities of 
customers' business models; connecting requests of novel solutions with potential, globally distributed providers (solvers, such as researchers, research organizations, lead users), developing and sustaining innovation networks and, finally, allowing outward and inward innovation commercialization (Howells, 2006; Tran et al., 2011; Colombo et al., 2014). The main functions can be comprehended as diverse phases of the innovation process:

(a) The search for innovation stage contains several functions: partners identification, suppliers' selection, and alternative options evaluation;

(b) The innovation transfer stage includes other relevant functions, such as: support to deal making, packaging of technology and innovation adaptation to users' needs (i.e, Howells, 2006).

According with Aquilani \& Abbate (2013), OIIs provide services classifiable in different ways.

Firstly, the support services are focused on sustaining the innovation processes in all its phases (i.e., text definition and revision of post by seekers, preventive analysis of idea/request/problem).

Secondly, communication services through a wide set of tools.

Thirdly, support services on complex technical elements that require specialized and focused competencies.

Fourthly consulting services regarding different aspects, such as legal, financial, technological, marketing.

Fifthy, services directed to discover and/or generate innovation opportunities.

All these services are provided through advanced technological platforms that help in meeting the collaboration activities and in exchanging of innovation seekers. In addition, they become the most relevant locus for the generation and the development of new ideas/knowledge (Bakici et al., 2010). By using advanced components and tools useful to differentiate the platforms, the OII coordinate and manage the needs of multiple actors in monitoring and controlling all the innovative process phases. (i.e., Innocentive) (Verona et al., 2006).

In doing so, one of the important roles of innovation intermediaries is the ability to harmonize all different competencies in order to activate, create and manage all the possible knowledge combination processes (Verona et al., 2006):

1) Positioning capability, as specific ability to operate as "bridge" within the knowledge market, by reducing informative asymmetry characterizing demand and offering;

2) Ability to acquire and to absorb the knowledge of contacted resources;

3) Ability to identify efficacious and efficient means for the commercialization of the innovative outcomes;

4) Ability to transfer knowledge among the involved internal/external resources;

5) Ability to facilitate the creation of relationships among diverse actors with different skills, competencies, professional experiences.

Innovation intermediaries stand out for their skills, expertise and knowledge, which cover a wide range of industries (Gassmann et al., 2010), although there are "specialist" cases, for example, Yet2.com, who concentrate their activities on the organization of virtual spaces for intellectual property exchange (Verona et al., 2006).

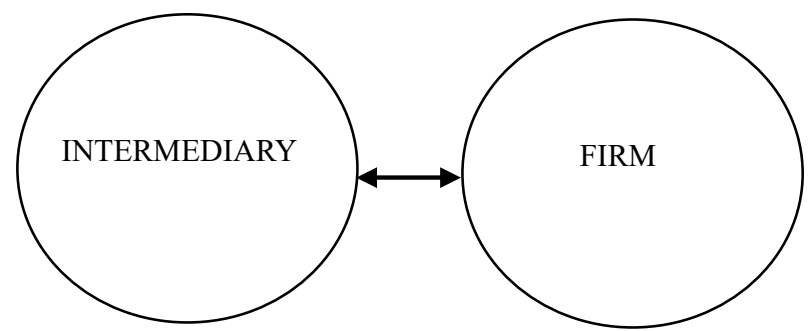

Figure 2. The necessary link between firms and Open Innovation Intermediaries

\subsection{Innovative Capacities}

One of the proprieties of global and dynamic business environment is to provide an ideal scenario of innovative possibilities for all types and size of firms, without geographic limitation to have access to knowledge. Not only, considering this property it has emerged for those firms a necessity to develop capacities to identify and use this knowledge with the aim to create value. Once identified this internal knowledge can be utilized as a platform to 
facilitate the absorption of "external knowledge" also denoted to as "inbound knowledge". According to Robertson et al. (2012), the innovative capacities for a firm have been defined as a set of dynamic capabilities that can guarantee that knowledge is accessed, acquired, managed and mobilised whenever and wherever the manager requires it necessary in achieving the strategic goals. From literature it is noted a significant agreement about the division in two different levels of capacities: first-order dynamic capabilities and second-order or master capacities (Easterby-Smith \& Prieto 2008; Ambrosini, Bowman \& Collier, 2009; Easterby-Smith et al. 2009; Robertson et al., 2012). The first-order capacities are observed as dynamic capabilities that can be effectively use to reconfiguring the organizational resource base (Schilke, 2014) where the second-order capabilities manage the first-order ones. In the context of innovation, a master capability is so labelled "innovative management capacity" and three types of first-order capabilities have been recognized: Accessive Capacity, Adaptive Capacity and Integrative Capacity (Robertson et al., 2012).

Due to the large amount of raw information available, a misjudgement on the potential importance of raw information might result in directing already scarce resources into decoding information that could ended up of little if no value for the firm. How a firm can then reduce this risk is by developing Accessive Capacity.

This capacity deals exclusively with finding, recognising and assimilating only information that can contribute to the firms overall' needs and exclude the rest. Despite the fact that firms may use particular strategies to collect information, in some cases and out of any strategy this can be the result of strong ties with long terms partners and/or in other instances it can be from weaker ties with geographically far away unknown intermediaries/suppliers (Granovetter, 1973).

When the right information has been accessed and assimilated by the firms, there are two possible scenarios:

a) knowledge does not perfectly match between the recently adopted knowledge/innovation (for example a new machine) and the current systems in place in the firm are very low. This situation can be only solved by Adaptive Capacity, which involves a capability to modify the recently assimilated knowledge and make it "ready to use" for the internal demands of the firm.

b) knowledge is compatible with the organization's systems and processes and therefore Integrative Capacity has the ability to ensure that the new knowledge is integrated effectively and in harmony within the firm.

The Innovative Management Capacity is a higher-level dynamic and flexible capability with the direct focus on coordinating (Easterby-Smith \& Prieto, 2008) first-level capacities (Accessive Capacity, Adaptive Capacity and Integrative Capacity) and at the same time to be responsive to organizational changes over time (Lichtenthaler \& Lichtenthaler, 2009).

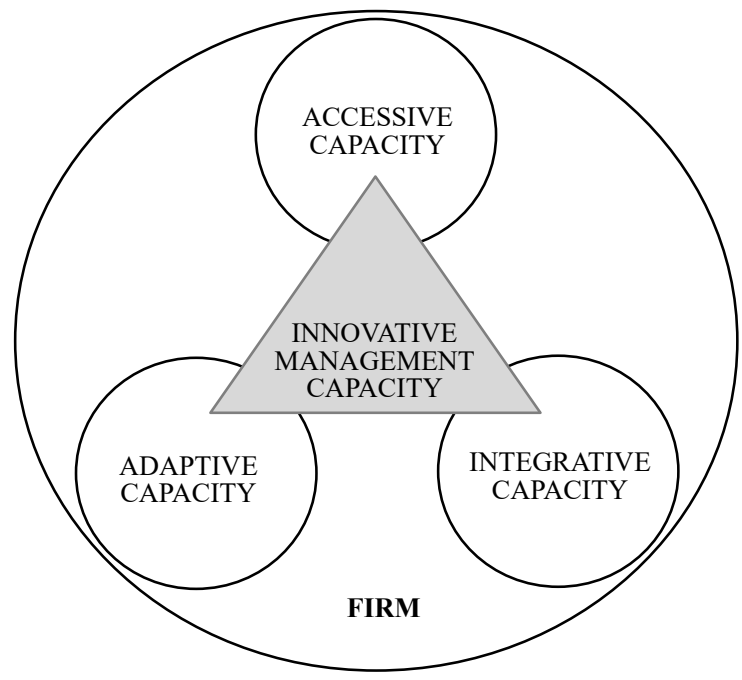

Figure 3. Organizational Innovative Capacities

As mentioned, Accessive Capacity operates as filter of wanted or necessary information into the firms. Adaptive and Integrative capacities both in different ways have the final purpose to allow the recently found knowledge to meet firms' needs and goals (see fig. 3). 


\section{Open Innovation Intermediaries Framework Development}

As discussed previously, the main purpose of this paper is to explain the possible relationship between firms and intermediaries in within the Service-Dominant logic premises and capitalising on the innovative capacities of both parties (firms and intermediaries) in an open source innovation space. Therefore, in order to describe such a complex scenario, a conceptual framework was advanced in order to show the critical role of each of the theories (Figure 4).

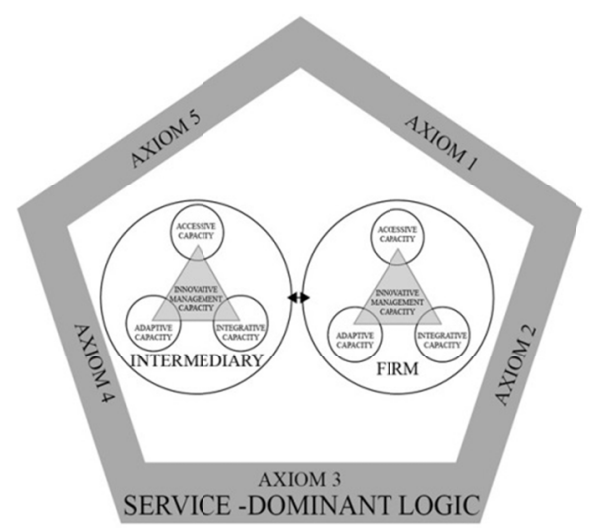

Figure 4. Framework for Open innovation intermediaries and firm exchange

The first part of the framework is characterised by five of the eleven premises from the S-D Logic also recently called the five axioms (Vargo \& Lusch, 2016):

1) service is the fundamental basis of exchange;

2) the customer is always a co-creator of value;

3) all social and economic actors are resource integrators;

4) value is always uniquely and phenomenological determined by the beneficiary and

5) value co-creation is coordinated through actor-generated institutions and institutional arrangements.

The frame provides the scenario in which the relationship between firm and intermediary occurs and the guiding principles of such exchange as well. Inside the frame, two large circles represent firms, intermediaries and their relationship (the arrow between the two). Inside each large circle (firm and intermediary) there are three small circles that symbolize three types of first order capacities (Accessive, Adaptive and Integrative) and a triangle connecting the tree circle which imply a higher order capacity called the Innovative management capacity that has the final aim of managingthe other three capacities (Robertson et al., 2012). Furthermore, knowing the existence of these two levels of organizational innovative capacities can provide a strong point for discussing possible direct and indirect benefits as a result of the nexus between firms and intermediaries. The relationship between the customer (the firm) and intermediaries is based on the exchange of information, knowledge and, competencies. In this exchange, the firm affects the value co-creation (developing of innovation capabilities) directly working with a specific innovation intermediary. It can be observed the existence of indirect benefits of such relationship that goes behind those directly involved and the recently created value could benefit both the firms and/or the intermediaries' communities (networks) at large (see tab.3). 
Table 3. Map of the influence of the S-D logic on individual and collective firms and intermediaries based on their innovative capacities

\begin{tabular}{|c|c|c|c|c|c|}
\hline & Innovative Capacity & $\begin{array}{l}\text { Firm } \\
\text { Direct }\end{array}$ & $\begin{array}{c}\text { Firms } \\
\text { Indirect }\end{array}$ & $\begin{array}{c}\text { Intermediary } \\
\text { Direct }\end{array}$ & $\begin{array}{c}\text { Intermediaries } \\
\text { Indirect }\end{array}$ \\
\hline \multirow{4}{*}{ AXIOM 1} & Accessive Capacity & $\mathrm{X}$ & $\mathrm{X}$ & $\mathrm{X}$ & $\mathrm{X}$ \\
\hline & Adaptive Capacity & $\mathrm{X}$ & $\mathrm{X}$ & $\mathrm{x}$ & $\mathrm{X}$ \\
\hline & Integrative Capacity & $\mathrm{X}$ & $\mathrm{X}$ & $\mathrm{X}$ & $\mathrm{X}$ \\
\hline & Innovative Management capacity & $\mathrm{X}$ & $\mathrm{X}$ & $\mathrm{X}$ & $\mathrm{X}$ \\
\hline \multirow{5}{*}{ AXIOM 2} & Accessive Capacity & $\mathrm{X}$ & - & $\mathrm{X}$ & - \\
\hline & Adaptive Capacity & $\mathrm{X}$ & - & $\mathrm{X}$ & - \\
\hline & Integrative Capacity & $\mathrm{X}$ & - & $\mathrm{X}$ & - \\
\hline & Innovative Management capacity & $\mathrm{X}$ & - & $\mathrm{X}$ & - \\
\hline & Accessive Capacity & - & $\mathrm{X}$ & - & $\mathrm{X}$ \\
\hline \multirow{3}{*}{ AXIOM 3} & Adaptive Capacity & - & $\mathrm{X}$ & - & $\mathrm{X}$ \\
\hline & Integrative Capacity & - & $\mathrm{X}$ & - & $\mathrm{X}$ \\
\hline & Innovative Management capacity & - & $\mathrm{X}$ & - & $\mathrm{X}$ \\
\hline \multirow{3}{*}{ AXIOM 4} & Accessive Capacity & $\mathrm{X}$ & $\mathrm{X}$ & $\mathrm{X}$ & $\mathrm{X}$ \\
\hline & Adaptive Capacity & $\mathrm{X}$ & $\mathrm{X}$ & $\mathrm{X}$ & $\mathrm{X}$ \\
\hline & Integrative Capacity & $\mathrm{X}$ & $\mathrm{X}$ & $\mathrm{X}$ & $\mathrm{X}$ \\
\hline \multirow{2}{*}{ AXIOM 5} & Innovative Management capacity & $\mathrm{X}$ & $\mathrm{X}$ & $\mathrm{X}$ & $\mathrm{X}$ \\
\hline & Innovative Management capacity & $\mathrm{X}$ & $\mathrm{X}$ & $\mathrm{X}$ & $\mathrm{X}$ \\
\hline
\end{tabular}

Based on the first axiom, the framework provides different types of possible service exchange between firm(s) and intermediaries. Direct service exchange between a firm and a particular intermediary occurs as a result of the individual need(s) identified by the internal innovative management capacity of that firm to further develop its first order capacities (accessive, adaptive and integrative). Once the higher-level capacity of the firm has identified which is the capacity(s) that requires the external support, then the most appropriate open innovation intermediaries in that area would be firstly identified and subsequently the most appropriate chosen. In return the chosen intermediary not only would have the chance to provide a service to the firm in exchange for financial retribution, but also to further improve its own innovative capacities while serving that customer (firm). For example, Firm Beta has recently purchased a new piece of equipment but it needs to integrate it into the overall production process and all the necessary knowledge to do that. The chosen intermediary (Alpha) firstly will collect and adjust the necessary knowledge and skills to better facilitate the integration of the recently purchased equipment into Firm Beta's production process. Secondly, in doing so, it will also further develop its own innovate management capacity in coordinating its first level capacities (accessive capacity in searching for the right information and also adapting and integrative capacity as possible selecting criteria) in fulfilling such a duty. Indirectly, the nexus between Firm Beta and the Intermediary Alpha has also provided new knowledge and skills that could be then passed on to other firms and intermediaries.

The second axiom by emphasizing the pivotal role that a customer as a co-creator of value offers the foundation for ensuring a collaborative relationship between a firm and the OII. It can also argue that the final value of a service exchange can be judged in terms of the degree of the cooperation, result of the interaction before, and then relationship, between the customer (firm), the intermediary and eventually the resource integrators.

The importance of the third axiom to the framework is related to the concept of capitalising on multiples networks as possible sources of knowledge and skills especially for integrate the independent outputs. In this case, also, the aspect of interaction and relationship is relevant to identify and understand which the most suitable actor and resource is (in order to shared value and, initially, not on the rules; and in order to the critical resources owned), with which to undertake a long-term relation. The emerging network can be seen as "[...] barycentre of many actors, representing the diffuse interests of the multitude of subjects "ensnared" in it meshes, both in the world of supply and the demand" (Polese, 2013, p. 83). When the equilibrium is reached between the legitimate expectations in the interests of the parties, and when knowledge and skills between actors in the network are shared, there are few reasons why the value cannot be cocreated.

The fourth axiom used in this framework is necessary to provide the concept of value and more importantly who decides the value are the beneficiaries and therefore the OII needs to compare that with what they possess in terms of knowledge and skills is of value to their customers. Each intermediary would have developed more or 
less one or more of the three first order capacities (accessive, adaptive and integrative), and consequently a firm might value OII in different ways not necessarily because of their intrinsic mix of those capabilities but more about the potential extrinsic benefit that such a mix of capabilities could bring back to the firm.

The fifth axiom in this framework assumes a particular relevance because the firm and intermediary have to develop innovative capabilities oriented to develop adequate practices - routinized activities - that are concretely institutions. These should enhance and/or obstacle the value cocreation activities (Vargo \& Lusch, 2016).

\section{Conclusion}

This study intends to enrich the management literature by applying a possible link among S-D logic, innovative capabilities and Open Innovation concepts. It aims are to develop an innovative framework focused on the relationship between firms and innovation intermediaries within the Service-Dominant logic premises by capitalising on the innovative capacities of both parties (firms and intermediaries).

The study has allowed us to reach some insights. Specifically, the OIIs can be concretely observed as service providers that create and provide useful web-based platforms and connected tools to stimulate, facilitate and support innovation processes/activities characterized by the involvement and the participation of different external resources and competencies. The critical activities of OIIs are linked to the capacity to create and maintain a successful innovation network. Additionally, the firms assume increasingly the important role of value co-creators (see table 3), by moving from the interaction and collaboration with different entities in order to accelerate, integrate and improve their internal innovation processes and to develop novel solutions for demand market.

The main contribution of this paper is to provide and develop a framework based on S-D Logic, Innovation Capabilities and Open Innovation Intermediaries point out the direct and indirect relationships and the necessity to better define and improve a set of innovative management capacities necessary to create and maintain efficacious innovation systems.

As this is a theoretical paper, there are a number of possible suggestions to develop it further such as the study of the degree of influence on the different innovative capabilities by the interactions showed in the framework in an empirical way. Therefore, by using a case studies methodology, its sequential research process with tools and techniques as e.g. interviews direct to top managers of innovative selected firms and intermediaries who have participated to a collected project) or by developing and administrating online surveys to a random sample of firms and intermediaries.

\section{References}

Abbate, T., \& Coppolino, R. (2011). Knowledge creation through knowledge brokers: some anecdotal evidence. Journal of Management Control, 22(3), 359- 371. http://dx.doi.org/10.1007/s00187-011-0144-5

Alter, S. (2008). Service System Innovation. In Barrett, M., Davidson, E., Middleton, C. \& DeGross, J. (Eds.), Information Technology in the Service Economy: Challenges and Possibilities for the 21st Century, (Vol. 267, pp. 61-80). IFIP (International Federation for Information Processing), Boston: Springer.

Ambrosini, V., Bowman, C., \& Collier, N. (2009). Dynamic capabilities: An exploration of how firms renew their resource base. British Journal of Management, 20(S1), S9-S24. https://doi.org/10.1111/j.1467-8551.2008.00610.x

American Marketing Association. (1960). Marketing Definitions, A Glossary of Marketing Terms, Committee on Definitions of the American Marketing Association. Chicago: American Marketing Association, p. 21.

Aquilani, B., \& Abbate, T. (2013). Le piattaforme di innovazione online: la prospettiva delle imprese. In Proceeding in Extenso XXV "Sinergie" Annual Conference "Innovation for business competitiveness", 24-25 October, Marche Polytechnic University, Ancona, Italy.

Aquilani, B., Abbate, T., \& Codini, A. (2017). Overcoming cultural barriers in open innovation processes through intermediaries: a theoretical framework. Knowledge Management Research and Practice, 15(3), 447-459. https://doi.org/10.1057/s41275-017-0067-5

Bakici, T., Almirall, E., \& Wareham, J. (2010). The underlying mechanisms of open innovation intermediaries. In European Commission, Information Society and Media Directorate-General and Open Innovation Strategy and Policy Group, Service innovation yearbook 2010-2011 (pp. 56-65). Brussels: EU. 
Blazevic, V., \& Lievens, A. (2008). Managing innovation through customer co-created knowledge in electronic services: An exploratory study. Journal of the Academy of Marketing Science, 36(1), 138-151. https://doi.org/10.1007/s11747-007-0064-y

Boudreau, K., \& Lakhani, K. (2009). How to Manage Outside Innovation: Competitive Markets or Collaborative Communities? MIT Sloan Management Review, 50(4), 69-75.

Brown, S. L., \& Eisenhardt, K. M. (1995). Product development: Past research, present findings, and future directions. Academy of Management Review, 20(2), 343-378.

Perano, M., Casali, G. L., \& Abbate T. (2016). Service Dominant Logic and Open Innovation Intermediaries: a possible meeting? In Caputo, F. (Ed.), e-Book of Abstract fourth International Symposium "Governing Business Systems. Theories and Challenges for System Thinking in Practice.

Chandler, J. D., \& Vargo, S. L. (2011). Contextualization and Value-in-context: How Context Frames Exchange. Marketing Theory, 11(1), 35-49. https://doi.org/10.1177/1470593110393713

Chesbrough, H. W. (2003a). Open Innovation: The New Imperative for Creating and Profiting from Technology. Boston: Harvard Business School Press.

Chesbrough, H. W. (2003b). The era of open innovation. MIT Sloan Management Review, 44(3), 35-41. Retrieved from https://sloanreview.mit.edu/article/the-era-of-open-innovation/

Chesbrough, H. W., \& Spohrer, J. (2006). A research manifesto for services science. Communications of the ACM, 49(7), 35-40. https://doi.org/10.1145/1139922.1139945

Chesbrough, H. W., Vanhaverbeke, W., \& West, J. (2006). Open innovation: A research agenda. In H. Chesbrough, W. Vanhaverbeke \& J. West (Eds.), Open innovation: Researching a new paradigm (pp. 285-307). Oxford: Oxford University Press.

Colombo, G., Dell'Era, C., \& Frattini, F. (2014). Exploring the contribution of innovation intermediaries to the new product development (NPD) process: A typology and an empirical study, R\&D Management, 45(2), 126-146. https://doi.org/10.1111/radm.12056

Dahlander, L., \& Gann, D. M. (2010). How open is innovation? Research Policy, 39(1), 699-709. https://doi.org/10.1016/j.respol.2010.01.013

Demirkan, H., Spohrer, J. C., \& Krishna, V. (Eds.) (2011). The Science of Service Systems. Boston: Springer. https://doi.org/10.1007/978-1-4419-8270-4

Easterby-Smith, M., \& Prieto, I. M. (2008). Dynamic Capabilities and Knowledge Management: an Integrative Role for Learning? British Journal of Management, 19(3), 235-249. https://doi.org/10.1111/j.1467-8551.2007.00543.x

Easterby-Smith, M., Lyles, M. A., \& Peteraf, M. A. (2009). "Dynamic Capabilities: Current Debates and Future Directions". British Journal of Management, 20(1), 1-8. https://doi.org/10.1111/j.1467-8551.2008.00609.x

Edvardsson, B., Tronvoll, B., \& Gruber T. (2011). Expanding understanding of service exchange and value co-creation: A social construction approach. Journal of the Academy of Marketing Science, 39(2), 327-339. https://doi.org/10.1007/s11747-010-0200-y

Enkel, E. (2010). Attributes required for profiting from open innovation in networks. International Journal of Technology Management, 52(3-4), 344-371. https://doi.org/10.1504/IJTM.2010.035980

Fitzsimmons, J. A., \& Fitzsimmons, M. J. (2006). Service Management: Operations, Strategy, and Information Technology (5th ed.). Boston: Irwin/McGraw-Hill.

Gassman, O. (2006). Opening Up the Innovation Process: Towards and Agenda. R\&D Management, 36(3), 223-228. https://doi.org/10.111/j.1467-9310.2006.00437.x

Gassman, O., Enkel, E., \& Chesbrough, H. (2010). The future of open innovation. R\&D Management, 40(3), 213-221. https://doi.org/10.1111/j.1467-9310.2010.00605.x

Granovetter, M. S., (1973). The Strength of Weak Ties. American Journal of Sociology, 78(6), 1360-1380. https://doi.org/10.1086/225469

Hakanson, L., Caessens, P., \& Macaulay, S. (2011). InnovationXchange: A case study in innovation intermediation. Innovation: Management, Policy \& Practice, 13(2), 261-274. https://doi.org/10.5172/impp.2011.13.2.261 
Hill, T. P. (1977). On Goods and Services. The Review of Income and Wealth, 23(4), 315-338.

Howells, J. (2006). Intermediation and the role of intermediaries in innovation. Research Policy, 35(7), 715-728. https://doi.org/10.1016/j.respol.2006.03.005

Hoffman, W. H., \& Scholesser, R. (2001). Success Factors of Strategic Alliances in Small and Medium-sized Enterprises-An Empirical Survey. Long Range Planning, 34(3), 357-381. https://doi.org/10.1016/S0024-6301(01)00041-3

Huizingh, E. K. R. E. (2011). Open innovation: State of the art and future perspectives. Technovation, 31(1), 2-9. https://doi.org/10.1016/j.technovation.2010.10.002

IfM and IBM. (2007). Succeeding through Service Innovation: White paper based on a Discussion Paper, University of Cambridge Institute for Manufacturing (IFM) and International Business Machines $\begin{array}{lll}\text { Corporation } & \text { (IBM). } & \text { Retrieved }\end{array}$ https://www.ifm.eng.cam.ac.uk/insights/servitization/succeeding-through-service-innovation

Kotler, P., \& Keller, K. (2006). Marketing Management (12th ed.), Upper Saddle River, NJ: Prentice Hall.

Lusch, R. F., \& Nambisan, S. (2015). Service innovation: A service-dominant logic perspective. MIS Quarterly: Management Information Systems, 39(1), 155-175.

Lusch, R. F., \& Vargo, S. L. (2006). The Service-Dominant Logic of Marketing: Dialog, Debate, and Directions. New York: Routledge.

Lusch, R. F., \& Vargo, S. L. (2014). Service-Dominant Logic. Premises, Perspectives, Possibilities. Cambridge: Cambridge University Press, UK.

Lichtenthaler, U., \& Lichtenthaler, E. (2009). A Capability-Based Framework for Open Innovation: Complementing Absorptive Capacity. Journal of Management Studies, 46(8), 1315-1338. https://doi.org/10.1111/j.1467-6486.2009.00854.x

Maglio, P. P., Vargo, S. L., Caswell, N., \& Spohrer, J. (2009). The Service System is the Basic Abstraction of Service Science". Information System and E-Business Management, 7(4), 395-406. https://doi.org/10.1007/s10257-008-0105-1

Merriam Webster Online. (2015). An encyclopedia of the Britannica Co. Retrived from http://www.merriam-webster.com/dictionary/interaction

Ollila, S., \& Elmquist, M. (2011). Managing Open Innovation: Exploring challenges at the interfaces of an open innovation arena. Creativity and Innovation Management, 20(4), 273-283. https://doi.org/10.1111/j.1467-8691.2011.00616.x

Polese, F. (2013). Management Sanitario in ottica sistemico vitale. Torino, IT: Giappichelli Editore.

Robertson, P. L., Casali, G. L. \& Jacobson, D. (2012). Managing open incremental process innovation: absorptive Capacity and distributed learning. Research Policy, 41(5), 822-832. https://doi.org/10.1016/j.respol.2012.02.008

Sampson, S. E., \& Froehle, C. M. (2006). Foundations and Implications of a Proposed Unified Services Theory. $\begin{array}{llll}\text { Production and } \quad \text { Operations } & \text { 329-343. }\end{array}$ https://doi.org/10.1111/j.1937-5956.2006.tb00248.x

Sawhney, M., Verona, G., \& Prandelli, E. (2005). Collaborating to create: The Internet as a platform for customer engagement in product innovation. Journal of Interactive Marketing, 19(4), 4-17. https://doi.org/10.1002/dir.20046

Schilke, O. (2014). Second-order dynamic capabilities: How do they matter? Academy of Management Perspectives, 28(4), 368-380. https://doi.org/10.5465/amp.2013.0093

Sieg, J. H., Wallin, M. W. \& von Krough, G. (2010). Managerial challenges in open innovations: a study of innovation intermediation in the chemical industry. R\&D Management, 40(3), 281-291. https://doi.org/10.1111/j.1467-9310.2010.00596.x

Spohrer, J. (2007). Service Science: The next frontier in service innovation. Retrived from https://www.ibm.com/developerworks/community/wikis/form/anonymous/api/wiki/ad5cdad0-33a1-46bc-8c ba-2102de0279ff/page/4c6bbe0b-577d-4eef-af47-5d62a83a3ad4/attachment/00803c7d-5404-4d5f-a7a8-6a9 8632c2bea/media/spohrer07int.pdf, last access 15/04/2015 
Spohrer, J. (2008). Services Sciences, Management, and Engineering (SSME) and Its Relation to Academic Disciplines. In Stauss B., Engelmann K., Kremer A. \& Luhn A. (Eds), Services Science (pp. 11-40). Berlin, Heidelberg: Springer. https://doi.org/10.1007/978-3-540-74489-4_2

Spohrer, J., \& Maglio, P. P. (2008). The emergence of service science: Toward systematic service innovations to accelerate co-creation of value. Production and Operation Management, 17(3), 1-9. https://doi.org/10.3401/poms.1080.0027

Spohrer, J., \& Maglio, P. P. (2009). Service science: Toward a smarter planet. In Karwowski, W. \& Salvendy G. (Eds.), Introduction to Service Engineering. New York: Wiley.

Spohrer, J., Anderson, L., Pass, N., \& Ager, T. (2008). Service science e service dominant logic. Otago Forum, 2 , 4-18.

Spohrer, J., Maglio, P. P., Bailey, J., \& Gruhl, D. (2007). Steps Towards a Science of Service Systems. Computer, 40(1), 71-77. https://doi.org/10.1109/MC.2007.33

Spohrer, J., Vargo, S., Maglio P. P., \& Caswell, N. (2008). The service system is the basic abstraction of service science. Paper presented at the $41^{\text {st }}$ Annual Hawaiian International Conference on Systems Sciences HICSS Conference, January 7-10.

Stewart, J., \& Hyysalo, S. (2008). Intermediaries, Users and Social Learning in Technological Innovation. International Journal of Innovation Management, 12(3), 295-325. https://doi.org/10.1142/S1363919608002035

Tran, Y., Hsuan, J., \& Mahnke, V. (2011). How do innovation intermediaries add value? Insight from new product development in fashion markets. $R \& D$ Management, 4l(1), 80-91. https://doi.org/10.1111/j.1467-9310.2010.00628.x

Van de Vrande, V., De Jong, J. P. J., Vanhaverbeke, W., \& De Rochemont, M. (2009). Open Innovation in SME's: trends, motives and management challenges. Technovation, 29, 423-437. https://doi.org/10.1016/j.technovation.2008.10.001

Vanhaverbeke, W., \& Du, J. (2010). Reframing the role of lead users in radical innovations: An open innovation perspective. International Journal of Business Environment, 3(2), 202-220. https://doi.org/10.1504/IJBE.2010.032715

Vargo, S. L. (2007). Paradigms, Pluralism, and Peripheries: On the Assessment of the S-D Logic. Australasian Marketing Journal, 15(1), 105-108. https://doi.org/10.1016/S1441-3582(07)70037-X

Vargo, S. L. (2008). On a theory of markets and marketing: from positively normative to normatively positive. Australasian Marketing Journal, 15(1), 53-60.

Vargo, S. L., \& Lusch, R. F. (2004). Evolving to a new dominant logic for marketing. Journal of Marketing, 68(1), 1-17. https://doi.org/10.1509/jmkg.68.1.1.24036

Vargo, S. L., \& Lusch R. F., (2006). Service-Dominant Logic: What It Is, What It Is Not, What It Might Be. In Lusch R. F. and Vargo S. L. (Eds.), The Service-Dominant Logic of Marketing: Dialog, Debate, and Directions, (pp. 43-56), Armonk, NY: M.E. Sharpe.

Vargo, S. L., \& Lusch, R. F. (2008). Service-dominant logic: Continuing the evolution. Journal of the Academy of Marketing Science, 36(1), 1-10. https://doi.org/10.1007/s11747-007-0069-6.

Vargo, S. L., \& Lusch, R. F. (2014). An Introduction to Service-Dominant Logic. Cambridge: Cambridge University Press.

Vargo, S. L., \& Lusch, R. F. (2016). Institutions and axioms: An extension and update of service-dominant logic. Journal of the Academy of Marketing Science, 44(4), 5-23. https://doi.org/10.1007/s11747-015-0456-3

Vargo, S. L., Maglio, P. P., \& Akaka, M. A. (2008). On value and value co-creation: A service systems and service logic perspective. European Management Journal, 26(3), 145-152. https://doi.org/10.1016/j.emj.2008.04.003

Verona, G., Prandelli, E., \& Sawhney, M. (2006). Innovation and virtual environments: towards virtual knowledge brokers. Organization Studies, 27(6), 765-788. https://doi.org/10.1177/0170840606061073

West, J., \& Gallagher, S. (2006). Challenges of open innovation: the paradox of firm investment in open-source software. $R \& D$ Management, 36(3), 319-331. https://doi.org/10.1111/j.1467-9310.2006.00436 
Ye, H., \& Kankanhalli, A. (2013). Exploring innovation through open networks: A review and initial research questions. IIMB Management Review, 25(2), 69-82. https://doi.org/10.1016/j.iimb.2013.02.002

\section{Copyrights}

Copyright for this article is retained by the author(s), with first publication rights granted to the journal.

This is an open-access article distributed under the terms and conditions of the Creative Commons Attribution license (http://creativecommons.org/licenses/by/4.0/). 